\title{
Simultaneous Multienzymatic Screening with Fluorogenic Probes
}

\author{
Maria L. S. O. Lima, ${ }^{a}$ Michel R. B. Chaves, ${ }^{a}$ Renato M. C. do Nascimento, ${ }^{a}$ \\ Caroline C. S. Gonçalves ${ }^{b}$ and Anita J. Marsaioli ${ }^{*, a}$ \\ ${ }^{a}$ Departamento de Química Orgânica, Instituto de Química, Universidade Estadual de Campinas, \\ P.O. Box 6154, 13084-971 Campinas-SP, Brazil \\ ${ }^{b}$ Instituto Latino-Americano de Ciências da Vida e da Natureza, \\ Universidade Federal da Integração Latino-Americana, \\ Av. Tancredo Neves, 6731, Bl. 6, 85867-970 Foz do Iguaçú-PR, Brazil
}

\begin{abstract}
The simultaneous screening of multiple enzyme activities in a single assay has numerous advantages over the traditional format, since it decreases sampling errors, allows savings in reagents and consumables and reduces the time and labor required to conduct the assays. In the present study, a direct and sensitive assay for the simultaneous detection of epoxide hydrolase and esterase (or lipase) activities was developed. Signal overlap is avoided by synthesizing fluorogenic probes with enzyme-specific alkyl linkers, connected to different fluorophores (resorfurin and umbelliferone), which exhibit emission spectra at different wavelengths. The simultaneous assays were conducted in microplate format with the fluorogenic probes monitored in the same well that uses microorganisms as enzyme source. Our results show that the fluorescent signal from each of the probes used here can be discriminated, allowing multiple enzyme activity detection and quantitation.
\end{abstract}

Keywords: multienzymatic screening, simultaneous detection, fluorogenic probes, hydrolases, cascade reaction

\section{Introduction}

Methodologies associated with fluorescent phenomena have led to the development of spectrophotometric techniques associated with sensors targeting biological applications. ${ }^{1-7}$ The fact that these techniques are based on the monitoring of absorption/emission wavelengths enables the simultaneous monitoring of different phenomena occurring in the same system by detecting different wavelengths. ${ }^{8,9}$ As such, multiplex assays ${ }^{10-12}$ are developed and applied to detect multiple transformations in a single experiment. They are often applied to high performance methodologies, where multiple analytes can be evaluated against a high number of samples. ${ }^{13}$ In the case of microplate assays, this allows the simultaneous and parallel monitoring of different biomolecules in a single system, paving the way for different and wider applications within the current biological context, such as the discovery of new biocatalysts of interest with the use of specific fluorogenic/chromogenic probes., ${ }^{41-17}$

The inclusion of biocatalytic steps in predominantly

*e-mail: anita@iqm.unicamp.br

This paper is part of the PubliSBQ Special Issue "IUPAC-2017" (http://publi.sbq.org.br/). chemical processes is an excellent alternative to improve parameters such as reaction conversion and selectivity; ${ }^{15}$ or even more complex cases, when it is aimed at obtaining a biocatalyst able to catalyze different substrates (enzymatic promiscuity). ${ }^{18,19}$ To that end, genetic engineering techniques have been used to improve catalytic potential through directed evolution processes..$^{20}$ These processes can lead to chemical and structural modifications of enzymes ${ }^{21}$ resulting in mutants with high or no specificity, making it possible to obtain biocatalysts ranging from the most enantioselective to the most promiscuous. ${ }^{22}$ This versatility contributes to their biotechnological application in industrial settings, where molecular engineering techniques, coupled with green chemistry processes, allow the production of high value-added inputs. ${ }^{23,24}$

As such, demand for these new biocatalysts requires rapid and sensitive methodologies to evaluate enzymatic activities, ${ }^{2,5,16,25}$ conversion, enantioselectivity $(E)^{9,14,26}$ and enantiomeric excess $(e e))^{3}$ Thus, spectrophotometric methods that use chromogenic ${ }^{27}$ or fluorogenic ${ }^{7,16,25}$ substrates as sensors are ideal for monitoring enzymatic activities. These methodologies are sensitive and require low concentrations of the substrate and biocatalyst, and 
are performed in miniaturized experiments ( $\mu \mathrm{L}$-scale) evaluating a large number of samples per unit of time., ${ }^{4,14}$ Since these tests monitor absorption (for chromophores) or emission (for fluorophores), more than one substrate can be evaluated at a time, ${ }^{9,28,29}$ provided that one wavelength does not overlap the other. Thus, the development of simultaneous monitoring systems for enzymatic activities becomes quite promising, contributing not only to cost savings, but to optimizing test times. ${ }^{29,30}$

Similar strategies are widely applied in life science research and clinical diagnostics for multiplexed analyses of target biomarkers. ${ }^{31-33}$ Multiplex immunoassays enable simultaneous analyses of different targets, requiring less sample and reagent than traditional enzyme-linked immunosorbent assays (ELISA), thereby simplifying and improving assay dynamics. This technology is applied to detect and quantify proteins, in addition to investigating cellular events and different diseases, such as cancer, ocular disorders and Kaposi's sarcoma-associated herpesvirus. ${ }^{33-37}$

In this regard, the present study proposes a methodology capable of simultaneously detect two enzymatic activities (epoxide-hydrolase and esterase or epoxide-hydrolase and lipase) in the same microorganism, with a miniaturized process involving two fluorogenic substrates (probes) that differ in the functional group, and fluorophores, both producing vicinal diols as products and releasing the fluorophore by sharing the same chemical cascade. This methodology was denominated multienzymatic screening.

\section{Experimental}

\section{General methods}

All chemical reactions were conducted under an $\mathrm{N}_{2}$ atmosphere using reagent grade solvents. All the reagents were purchased from Sigma-Aldrich Co., Germany, and used without further purification. Fluorogenic probes $\mathbf{4 a}$ and $\mathbf{4 c}$ were previously synthesized by our research group, according to Reymond's methodology. ${ }^{14}$ Flash column chromatography was performed using normal phase silica gel. The spots on analytical thin-layer chromatography (TLC) plates were visualized under ultraviolet light or visible light (it is not necessary to use chemical solutions because the resorufin derivatives are colored). ${ }^{1} \mathrm{H}$ nuclear magnetic resonance (NMR) spectra were recorded on Bruker spectrometers $(400$ or $500 \mathrm{MHz})$. Chemical shifts $(\delta)$ are reported in parts per million $(\mathrm{ppm})$ relative to the internal standard tetramethylsilane $\left(\mathrm{Si}\left(\mathrm{CH}_{3}\right)_{4}=0.00 \mathrm{ppm}\right)$ or residual solvent peaks $\left(\mathrm{CDCl}_{3}\right.$ or dimethyl sulfoxide (DMSO)). ${ }^{1} \mathrm{H}$ NMR coupling constants $(J)$ are reported in hertz $(\mathrm{Hz})$, and multiplicity is indicated as follows: s (singlet), d (doublet), $\mathrm{t}$ (triplet), q (quartet), m (multiplet), s (singlet), dd (doublet of doublet), dq (doublet of quartet). ${ }^{13} \mathrm{C}$ NMR spectra were recorded at 100 or $125 \mathrm{MHz}$, and all chemical shift values are reported in ppm on the $\mathrm{d}$ scale, with an internal reference of $\mathrm{CDCl}_{3}$ or DMSO. Fluorescence spectra and the enzymatic assays were recorded with a 2300 EnSpire Multimodal Reader (PerkinElmer). All microorganisms were obtained from CCT (Tropical Cultures Collection, André Tosello Foundation, Campinas, Brazil) or ATCC (American Type Culture Collection, Manassas, USA). All culture media used in this study were purchased from Oxoid (Brazil).

\section{Enzymatic assays}

All assays were performed in quadruplicate in 96-well microtitre plates (with $200 \mu \mathrm{L}$ in each well) and incubated at $28^{\circ} \mathrm{C}$ and $180 \mathrm{rpm}$ for $24 \mathrm{~h}$. The assays (enzymatic assays, negative controls and positive controls) were monitored simultaneously, according to umbeliferone $\left(\lambda_{\mathrm{ex}}=370 \mathrm{~nm}\right.$ and $\left.\lambda_{\mathrm{em}}=470 \mathrm{~nm}\right)$ and resorufin $\left(\lambda_{\mathrm{ex}}=570 \mathrm{~nm}\right.$ and $\lambda_{\mathrm{em}}=590 \mathrm{~nm}$ ) wavelengths.

\section{Screening of microorganisms used in the assays}

\section{Enzymatic assay}

Each well was added with $\mathrm{NaIO}_{4}\left(10 \mu \mathrm{L}, 20 \mathrm{mmol} \mathrm{L}^{-1}\right.$ in water), BSA (bovine serum albumin, $80 \mu \mathrm{L}, 5.0 \mathrm{~g} \mathrm{~L}^{-1}$ in borate buffer, $\mathrm{pH}$ 7.8), fluorescent probe $\mathbf{3}, \mathbf{4 a}$ or $\mathbf{4 b}$ $\left(10 \mu \mathrm{L}, 1 \mathrm{mmol} \mathrm{L}^{-1}\right.$ in DMSO $)$ and cell suspension $(100 \mu \mathrm{L}$; $0.2 \mathrm{~g} \mathrm{~L}^{-1}$ for bacteria and yeast; $1.0 \mathrm{~g} \mathrm{~L}^{-1}$ for fungi) in borate buffer, $\mathrm{pH} 7.8$.

\section{Negative control}

Each well was added with $\mathrm{NaIO}_{4}\left(10 \mu \mathrm{L}, 20 \mathrm{mmol} \mathrm{L}{ }^{-1}\right.$ in water), BSA ( $80 \mu \mathrm{L}, 5.0 \mathrm{~g} \mathrm{~L}^{-1}$ in borate buffer, $\left.\mathrm{pH} 7.8\right)$, fluorescent probe 3 , $4 \mathbf{a}$ or $\mathbf{4 b}\left(10 \mu \mathrm{L}, 1 \mathrm{mmol} \mathrm{L}^{-1}\right.$ in DMSO $)$ and borate buffer $\mathrm{pH} 7.8(100 \mu \mathrm{L})$.

\section{Positive control}

Each well was added with $\mathrm{NaIO}_{4}\left(10 \mu \mathrm{L}, 20 \mathrm{mmol} \mathrm{L}^{-1}\right.$ in water), BSA ( $80 \mu \mathrm{L}, 5.0 \mathrm{~g} \mathrm{~L}^{-1}$ in borate buffer, $\mathrm{pH} 7.8$ ), 5 or diol $6\left(10 \mu \mathrm{L}, 1 \mathrm{mmol} \mathrm{L}^{-1}\right.$ in DMSO) and cell suspension $\left(100 \mu \mathrm{L} ; 0.2 \mathrm{~g} \mathrm{~L}^{-1}\right.$ for bacteria and yeast; $1.0 \mathrm{~g} \mathrm{~L}^{-1}$ for fungi) in borate buffer, $\mathrm{pH}$ 7.8.

\section{Multienzymatic assay}

After being screened with each probe $(\mathbf{3}, \mathbf{4 a}$ and $\mathbf{4 b})$, the microorganisms were evaluated in multi-enzymatic assays involving two fluorogenic probes simultaneously. The assays were incubated at $28{ }^{\circ} \mathrm{C}$ with orbital shaking 
in a 2300 EnSpireTM Multimodal Reader (PerkinElmer) for $10 \mathrm{~h}$ and monitored every $15 \mathrm{~min}$ in the umbelliferone $\left(\lambda_{\mathrm{ex}}=370 \mathrm{~nm}\right.$ and $\left.\lambda_{\mathrm{em}}=470 \mathrm{~nm}\right)$ and resorufin $\left(\lambda_{\mathrm{ex}}=570 \mathrm{~nm}\right.$ and $\lambda_{\text {em }}=590 \mathrm{~nm}$ ) wavelengths, simultaneously. The 2300 EnSpireTM Multimodal Reader (PerkinElmer) enables simultaneous monitoring of two different emission wavelengths in the same well.

\section{Enzymatic assay}

Each well was added with $\mathrm{NaIO}_{4}\left(10 \mu \mathrm{L}, 20 \mathrm{mmol} \mathrm{L}^{-1}\right.$ in water), BSA (70 $\mu \mathrm{L}, 5.7 \mathrm{~g} \mathrm{~L}^{-1}$, in borate buffer, $\mathrm{pH} 7.8$ ), fluorescent probe $\mathbf{3}$ and $\mathbf{4 a}$ or $\mathbf{4 b}\left(10 \mu \mathrm{L}, 0.5 \mathrm{mmol} \mathrm{L}^{-1}\right.$ in DMSO) and cell suspension ( $100 \mu \mathrm{L} ; 0.2 \mathrm{~g} \mathrm{~L}^{-1}$ for bacteria and yeast; $1.0 \mathrm{~g} \mathrm{~L}^{-1}$ for fungi) in borate buffer, $\mathrm{pH}$ 7.8.

\section{Negative control}

Each well was added with $\mathrm{NaIO}_{4}\left(10 \mu \mathrm{L}, 20 \mathrm{mmol} \mathrm{L}{ }^{-1}\right.$ in water), BSA (70 $\mu \mathrm{L}, 5.7 \mathrm{~g} \mathrm{~L}^{-1}$ in borate buffer, $\mathrm{pH} 7.8$ ), fluorescent probe 3 and $4 \mathbf{a}$ or $\mathbf{4 b}\left(10 \mu \mathrm{L}, 0.5 \mathrm{mmol} \mathrm{L}^{-1}\right.$ in DMSO) and borate buffer $\mathrm{pH} 7.8(100 \mu \mathrm{L})$.

\section{Positive control}

Each well was added with $\mathrm{NaIO}_{4}\left(10 \mu \mathrm{L}, 20 \mathrm{mmol} \mathrm{L}{ }^{-1}\right.$ in water), BSA (70 $\mu \mathrm{L}, 5.7 \mathrm{~g} \mathrm{~L}^{-1}$ in borate buffer, $\mathrm{pH} 7.8$ ), 5 and 6 diol (10 $\mu \mathrm{L}, 0.5 \mathrm{mmol} \mathrm{L}^{-1}$ in DMSO) and cell suspension $\left(100 \mu \mathrm{L} ; 0.2 \mathrm{~g} \mathrm{~L}^{-1}\right.$ for bacteria and yeast; $1.0 \mathrm{~g} \mathrm{~L}^{-1}$ for fungi) in borate buffer, $\mathrm{pH} 7.8$.

\section{Chemical synthesis}

\section{7-(But-3-en-1-yloxy)-3H-phenoxazin-3-one (7) ${ }^{1}$}

$\mathrm{K}_{2} \mathrm{CO}_{3}(0.126 \mathrm{~g}, 0.9 \mathrm{mmol}, 2.0$ equiv. $)$ and resorufin sodium salt $(0.96 \mathrm{~g}, 0.4 \mathrm{mmol}, 1.0$ equiv.) were added to a solution of 3-butene-1-(p-toluenesulfonate) $(0.100 \mathrm{~g}, 0.44 \mathrm{mmol}$, 1.0 equiv.) in anhydrous DMF (dimethylformamide, $7.0 \mathrm{~mL}$ ). The mixture reaction was refluxed at $110^{\circ} \mathrm{C}$ for $1 \mathrm{~h}$ under $\mathrm{N}_{2}$. After cooling, the mixture was diluted with $\mathrm{CH}_{2} \mathrm{Cl}_{2}(50 \mathrm{~mL})$ and washed with water $(35 \mathrm{~mL} \times 2)$ and brine $(35 \mathrm{~mL} \times 4)$, respectively. The organic layer was separated, dried over $\mathrm{MgSO}_{4}$ and the solvent was removed under reduced pressure, resulting in the pure product (orange solid product) $(0.119 \mathrm{~g}, 90.1 \%) .{ }^{1} \mathrm{H} \mathrm{NMR}\left(400 \mathrm{MHz}, \mathrm{CDCl}_{3}\right) \delta 7.81(1 \mathrm{H}$, d, $J 8.0 \mathrm{~Hz}), 7.54(1 \mathrm{H}, \mathrm{d}, J 10.0 \mathrm{~Hz}), 7.06(1 \mathrm{H}, \mathrm{dd}, J 2.4$ and $8.8 \mathrm{~Hz}), 6.95(1 \mathrm{H}, \mathrm{dd}, J 2.0$ and $10.0 \mathrm{~Hz}), 6.92(1 \mathrm{H}, \mathrm{d}$, $J 2.5 \mathrm{~Hz}), 6.43(1 \mathrm{H}, \mathrm{d}, J 2.0 \mathrm{~Hz}), 6.05(1 \mathrm{H}, \mathrm{m}), 5.35(1 \mathrm{H}, \mathrm{dq}$, $J 1.6,2.8$ and $17.2 \mathrm{~Hz}), 5.29(1 \mathrm{H}, \mathrm{dq}, J 1.6,2.8$ and $8.8 \mathrm{~Hz})$, $4.25(2 \mathrm{H}, \mathrm{t}, J 6.8 \mathrm{~Hz}), 2.75(2 \mathrm{H}, \mathrm{m}) ;{ }^{13} \mathrm{C}$ NMR $(100 \mathrm{MHz}$, $\left.\mathrm{CDCl}_{3}\right) \delta 186.5,163.2,150.0,145.8,145.6,134.9,134.3$, 133.7, 131.7, 128.5, 117.9, 114.2, 106.9, 100.7, 68.4, 33.4. Electron impact-mass spectrometry (EI-MS, $\mathrm{m} / \mathrm{z}$ ) was calculated for $\mathrm{C}_{16} \mathrm{H}_{13} \mathrm{NO}_{3}, 267.09$; found, 267.30.
7-(2-(Oxiran-2-yl)ethoxy)-3H-phenoxazin-3-one (3) ${ }^{1}$

A solution of $7(0.150 \mathrm{~g}, 0.6 \mathrm{mmol}, 1$ equiv. $)$ in anhydrous $\mathrm{CH}_{2} \mathrm{Cl}_{2}(6 \mathrm{~mL})$ was treated at $0{ }^{\circ} \mathrm{C}$ with $77 \%$ $m$-CPBA ( $0.250 \mathrm{~g}, 1.12 \mathrm{mmol}, 2$ equiv.). After $16 \mathrm{~h}$ at $0{ }^{\circ} \mathrm{C}$, the solution was washed with $10 \%$ aqueous $\mathrm{Na}_{2} \mathrm{SO}_{3}$ $(10 \mathrm{~mL} \times 3), 5 \%$ aqueous $\mathrm{NaOH}(10 \mathrm{~mL} \times 3)$ and water $(10 \mathrm{~mL} \times 2)$, respectively. The organic layer was evaporated and the solid was purified by flash chromatography $\left(\mathrm{CH}_{2} \mathrm{Cl}_{2}\right.$ :acetone 1:19) to give $\mathbf{3}(0.708 \mathrm{~g}, 53 \%)$ as an orange solid. ' ${ }^{\mathrm{H}} \mathrm{NMR}(500 \mathrm{MHz}, \mathrm{DMSO}) \delta 7.77(1 \mathrm{H}, \mathrm{d}, J 9.0 \mathrm{~Hz})$, $7.53(1 \mathrm{H}, \mathrm{d}, J 10.0 \mathrm{~Hz}), 7.14(1 \mathrm{H}, \mathrm{d}, J 2.5 \mathrm{~Hz}), 7.07(1 \mathrm{H}$, dd, $J 2.5$ and $9.0 \mathrm{~Hz}), 6.79(1 \mathrm{H}$, dd, $J 2.0$ and $9.5 \mathrm{~Hz}), 6.26$ $(1 \mathrm{H}, \mathrm{d}, J 2.0 \mathrm{~Hz}), 4.26(2 \mathrm{H}, \mathrm{t}, J 6.5 \mathrm{~Hz}), 3.09(1 \mathrm{H}, \mathrm{m}), 2.74$ $(1 \mathrm{H}, \mathrm{t}, J 4.5 \mathrm{~Hz}), 2.56(\mathrm{H}, \mathrm{dd}, J 3.0$ and $5.5 \mathrm{~Hz}), 2.03(1 \mathrm{H}$, m), $1.92(1 \mathrm{H}, \mathrm{m}) ;{ }^{13} \mathrm{C}$ NMR (125 MHz, DMSO) $\delta 185.8$, 163.0, 150.2, 145.8, 145.7, 135.4, 134.2, 131.8, 128.4, 114.6, 106.1, 101.3, 66.5, 49.5, 46.6, 32.0. EI-MS $(\mathrm{m} / \mathrm{z})$ calculated for $\mathrm{C}_{16} \mathrm{H}_{13} \mathrm{NO}_{4}, 283.08$; found, 283.30.

\section{Results and Discussion}

Multienzymatic screening assays consist of the simultaneous monitoring of two or more enzymatic activities in the same microorganism. These assays are recommended to rapidly assess the activity of a large number of samples, since more than one enzyme activity can be detected in a single assay. In this respect, fluorogenic probes derived from resorufin (1) and umbelliferone (2) (Figure 1) were used in a multicomponent assay that allowed the simultaneous detection of epoxide hydrolases (resorufin-based probe $\mathbf{3}$ ) 37 and esterases (umbelliferone-based probes $\mathbf{4 a}$ and $\mathbf{4 b}$ ) (Scheme 1). ${ }^{3,14}$ Signal independence for each target enzyme was achieved because the fluorophores employed, resorufin $\left(\lambda_{\mathrm{ex}}=570 \mathrm{~nm}, \lambda_{\mathrm{em}}=590 \mathrm{~nm}\right)$ and umbelliferone $\left(\lambda_{\mathrm{ex}}=370 \mathrm{~nm}, \lambda_{\mathrm{em}}=470 \mathrm{~nm}\right)$, have different excitation and emission wavelengths, thereby avoiding interference with the simultaneous detection of the fluorescence signal corresponding to each enzyme activity (Figure 1).

The multicomponent assays to detect epoxide hydrolases and esterases were performed simultaneously in a single microplate well. In addition, the enzymatic hydrolysis products of probes $\mathbf{3}, \mathbf{4 a}$ and $\mathbf{4 b}$ are analogous (vicinal diols) and therefore participate in the same chemical cascade, triggered by specific enzymes. This chemo-enzymatic cascade model has been widely applied by our research group and was initially published by Reymond and co-workers in their research works. ${ }^{14,38}$ The cascade involves oxidative cleavage of the diols (caused by the action of $\mathrm{NaIO}_{4}$ ) followed by in situ $\beta$-elimination (triggered by BSA) and release of the fluorophores. This makes it possible to simultaneously detect the 


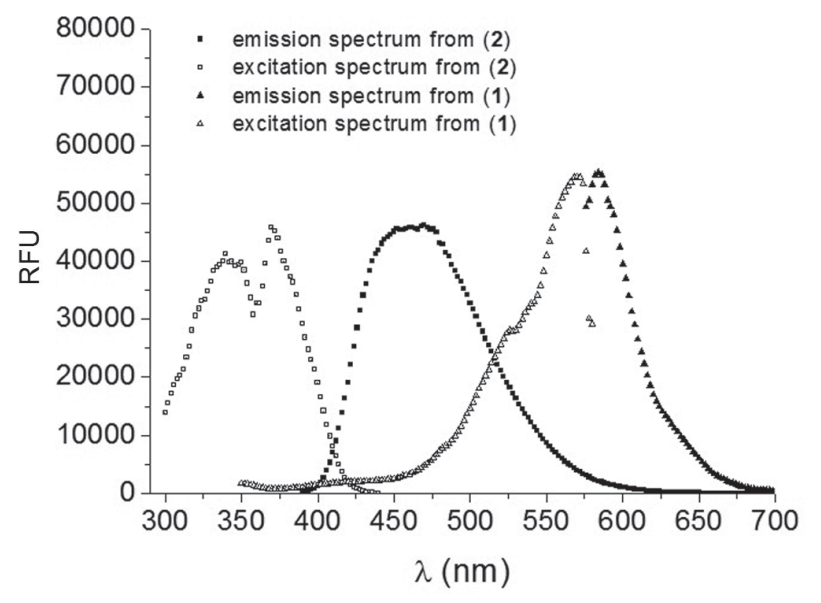

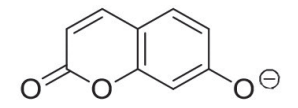

(2)

$\lambda_{\text {ex }}=370 \mathrm{~nm}$

$\lambda_{\mathrm{em}}=470 \mathrm{~nm}$

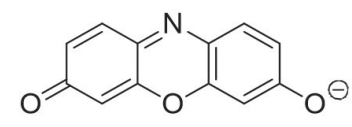

(1)

$\lambda_{\mathrm{ex}}=570 \mathrm{~nm}$

$\lambda_{\mathrm{em}}=590 \mathrm{~nm}$
Figure 1. Resorufin (1) and umbelliferone (2) emission and excitation spectra in borate buffer $\mathrm{pH} 7.8$.

two enzymatic activities in the same microplate well (Scheme 1).

\section{Microorganism screening with fluorogenic probes}

Implementation of the multienzymatic screening methodology with microorganisms adhered to the following protocol: first, the experiments were performed with each of the selected strains: 13 bacteria (Acinetobacter baumanni, CCT: 1432; Agrobacterium tumefaciens, CCT: 6515; Bacillus cereus, CCT: 4060; Proteus mirabilis, CCT: 1473; Pseudomonas aeruginosa, CCT: 1987; Pseudomonas oleovorans, СCT:1969; Serratia liquefaciens, CCT: 1479; Yersinia intermedia, CCT: 1600; Xanthomonas maltophilia, CCT: 1897; Corynebacterium xerosis, ATCC: 373; Serratia plymuthica, CCT: 2023; Micrococcus luteus, CCT:2720 and Bacillus subtilis, CCT: 89), 5 yeasts (Pichia stipites, CCT: 2617; Pachysolen tannophilus, CCT: 1891; Rhodotorula glutinis, CCT: 2182; Saccharomyces cerevisiae, CCT: 771 and Kluyveromyces marxianus, CCT: 2393) and 8 fungi (Geotrichum candidum, CCT: 1205; Rhizopus oryzae, CCT: 4964; Curvularia lunata, CCT: 5628; Curvularia eragrostidis, CCT: 5634; Emericella nidulans, CCT: 3119; Aspergillus fumigatus, CCT:1277; Mortierella isabelina, CCT: 3498 and Beauveria bassiana, CCT: 4448) from André Tosello Foundation Tropical Cultures Collection (CCT), available at LaBioChem (Institute of Chemistry, UNICAMP). The strains were evaluated $(\mathbf{3}, \mathbf{4} \mathbf{a}$ and $\mathbf{4 b})$ individually (Table 1$)$ to determine which ones showed activity for probes with different fluorophores ( $\mathbf{3}$ and $\mathbf{4 a}$ or $\mathbf{3}$ and $\mathbf{4 b}$ ) (Scheme 1).

The assays were performed in 96-well microplates, with quadruplicates of the assays and duplicates of the negative and positive controls, and monitored for $24 \mathrm{~h}$. The results were expressed as conversion in percentage (Table 1), where the fluorescent signal shows how much of the

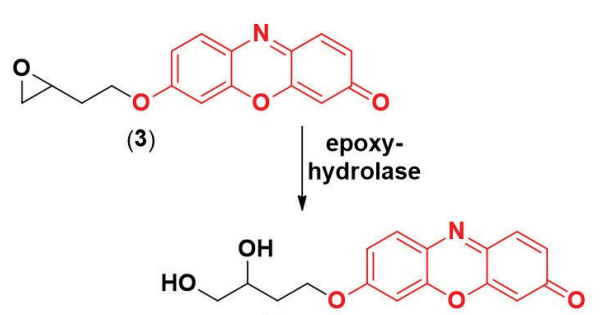

(5)

1) $\mathrm{NaIO}_{4}$

2) $\beta$-elimination

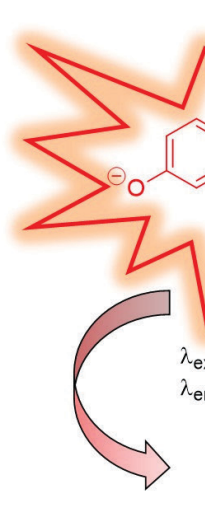

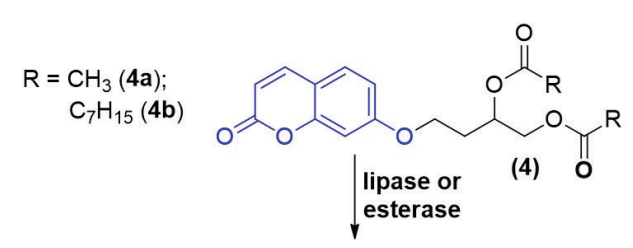

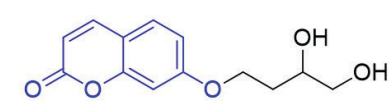

(6)

1) $\mathrm{NaIO}_{4}$

2) $\beta$-elimination

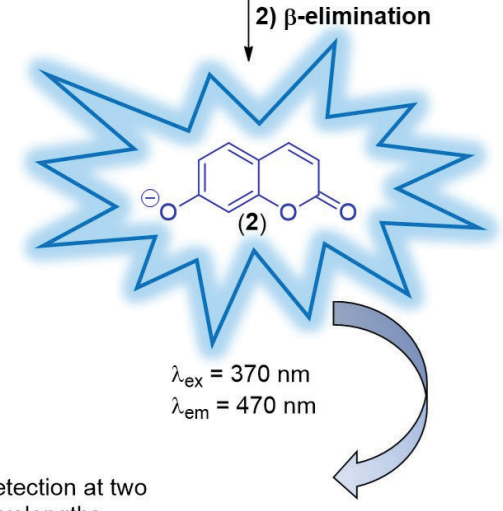

Simultaneous detection at two different wavelengths 
Table 1. Conversions of the enzymatic reactions with each probe after $24 \mathrm{~h}$

\begin{tabular}{|c|c|c|c|c|c|}
\hline & \multirow{2}{*}{ Microorganism } & \multirow{2}{*}{$\mathrm{CCT}^{\mathrm{a}}$} & \multicolumn{3}{|c|}{ Conversion after $24 \mathrm{~h} / \%$} \\
\hline & & & Probe 3 & Probe $\mathbf{4 a}$ & Probe $\mathbf{4 b}$ \\
\hline \multirow{13}{*}{ Bacterium } & Acinetobacter baumanni & 1432 & 8.7 & 9.9 & 12.4 \\
\hline & Agrobacterium tumefaciens & 6515 & 2.0 & 2.6 & 21.5 \\
\hline & Bacillus cereus & 4060 & 8.7 & 18.7 & 51.9 \\
\hline & Bacillus subtilis & 89 & 1.3 & 1.1 & 35.6 \\
\hline & Corynebacterium xerosis & $\mathrm{ATCC}^{\mathrm{b}}$ & 8.3 & 2.9 & 23.1 \\
\hline & Micrococcus luteus & 2720 & 0.6 & 0.2 & 0.1 \\
\hline & Proteus mirabilis & 1473 & 0.5 & 0.1 & 0.1 \\
\hline & Pseudomonas aeruginosa & 1987 & 1.0 & 7.5 & 13.2 \\
\hline & Pseudomonas oleovorans & 1969 & 7.1 & 10.0 & 12.9 \\
\hline & Serratia liquefaciens & 1476 & 1.9 & 28.1 & 6.9 \\
\hline & Serratia plymuthica & 2023 & 0.3 & 16.6 & 8.9 \\
\hline & Yersinia intermedia & 1600 & 0.4 & 0.1 & 0.3 \\
\hline & Xanthomonas maltophilia & 1897 & 1.3 & 0.1 & 1.8 \\
\hline \multirow{5}{*}{ Yeast } & Kluyveromyces marxianus & 2393 & 0.3 & 0.4 & 1.1 \\
\hline & Pachysolen tannophilus & 1891 & 0.1 & 0.2 & 0.2 \\
\hline & Pichia stipitis & 2617 & 0.8 & 4.5 & 24.4 \\
\hline & Rhodotorula glutinis & 2182 & 28.5 & 4.0 & 2.2 \\
\hline & Saccharomyces cerevisiae & 771 & 0.2 & 0.1 & 0.1 \\
\hline \multirow{7}{*}{ Fungus } & Aspergillus fumigatus & 1277 & 0.3 & 0.1 & 0.4 \\
\hline & Beauveria bassiana & 4448 & 0.1 & 0.23 & 0.2 \\
\hline & Curvularia eragrostidis & 5634 & 5.4 & 15.5 & 0.5 \\
\hline & Curvularia lunata & 5628 & 12.5 & 4.2 & 4.3 \\
\hline & Emericella nidulans & 3119 & 0.2 & 22.8 & 2.5 \\
\hline & Geotrichum candidum & 1205 & 1.6 & 24.8 & 1.0 \\
\hline & Mortierella isabelina & 3498 & 7.8 & 9.7 & 5.9 \\
\hline
\end{tabular}

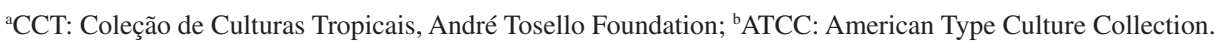

substrate (probe) was converted into its respective product via chemo-enzymatic reaction (Scheme 1). Conversion percentages of the enzymatic reactions were calculated according to the equation 1 :

Conversion $(\%)=\frac{\left(\begin{array}{c}\text { mean RFU } \\ \text { of assays }\end{array}\right)-\left(\begin{array}{c}\text { mean RFU of } \\ \text { negative controls }\end{array}\right)}{(\text { mean RFU of positive controls })} \times 100$

where RFU of assays is the relative fluorescence unit corresponding to each well of the assayed microplate; RFU of negative controls represents the spontaneous hydrolysis of the probes used and RFU of positive controls represents a $100 \%$ conversion assay, i.e., the maximum fluorescence intensity. Based on the conversions observed after $24 \mathrm{~h}$ (Table 1), the bacterium Bacillus cereus (CCT: 4060), the yeast Rhodotorula glutinis (CCT: 2182) and the fungus
Curvularia lunata (CCT: 5628) were selected to test the multi-enzymatic screening methodology.

\section{Multienzymatic screening assays}

The multienzimatic screening assays were carried out with Bacillus cereus (CCT: 4060), Rhodotorula glutinis (CCT: 2182) and Curvularia lunata (CCT: 5628) using probes $\mathbf{3}$ and $\mathbf{4 a}$ (resorufin and umbelliferonederived probes, respectively). The same assay monitored both hydrolytic activities over the same time interval (see Scheme 1 and Figure 2). The same procedure was adopted for the simultaneous monitoring assay of probes $\mathbf{3}$ and $\mathbf{4 b}$.

Since resorufin is also detected in the visible region (Figure 1), in addition to fluorescence, a change is observed in the assay color when compared to the negative control 

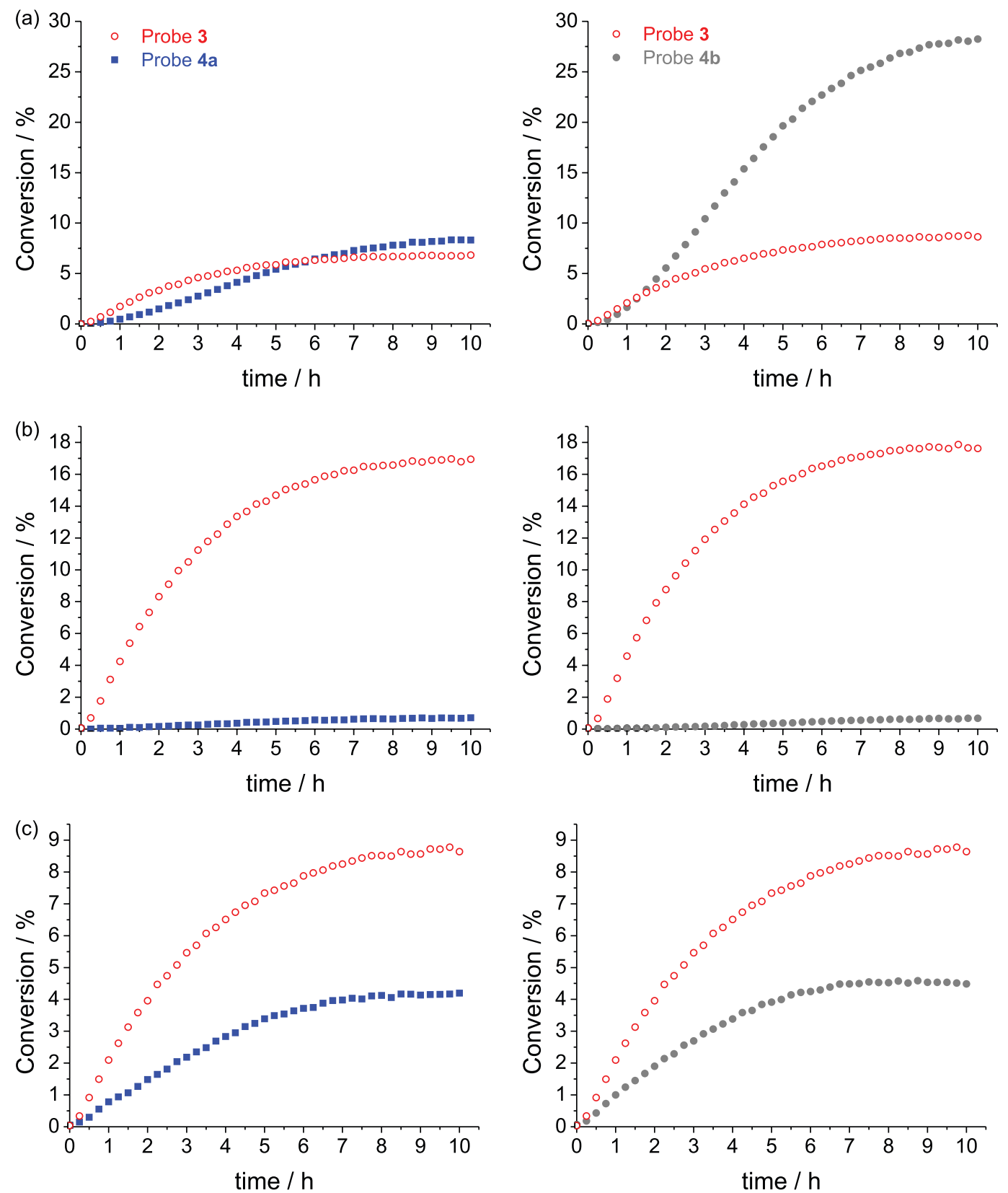

Figure 2. Graphs of the simultaneous detections of probes $\mathbf{3}$ and $\mathbf{4 a}$ (left) and probes $\mathbf{3}$ and $\mathbf{4 b}$ (right) in the assays performed with (a) Bacillus cereus (CCT-4060); (b) Rhodotorula glutinis (CCT-2182) and (c) Curvularia lunata (CCT-5628) microorganisms.

(Figure 3), indicating the liberation of resorufin (caused by chemo-enzymatic cascade) and, consequently, revealing the presence of the enzymatic activity investigated. Given that umbelliferone is excited at around $370 \mathrm{~nm}$ and therefore emits at about $470 \mathrm{~nm}$ (blue), it cannot be observed under visible light, requiring a $354 \mathrm{~nm}$ UV light lamp for visualization, as shown in Figure 3.

This assay reveals that the reaction is in progress by changing the color of the reaction medium. When the chemo-enzymatic cascade is in progress, the resorufin (purple color) and the substrate (3) mix-up producing the color depicted in the Figure 3. Therefore, this color change can be taken as a visual qualitative evidence of the enzymatic reaction.

After monitoring, it was possible to simultaneously detect both enzymatic activities in the well, expressed by the same microorganism using fluorogenic probes $\mathbf{3}$ and $\mathbf{4 a}$ or $\mathbf{3}$ and $\mathbf{4 b}$, which confirmed the efficiency of the proposed methodology.

\section{Conclusions}

The proposed methodology is highly efficient, allowing the simultaneous monitoring of two hydrolytic activities in 


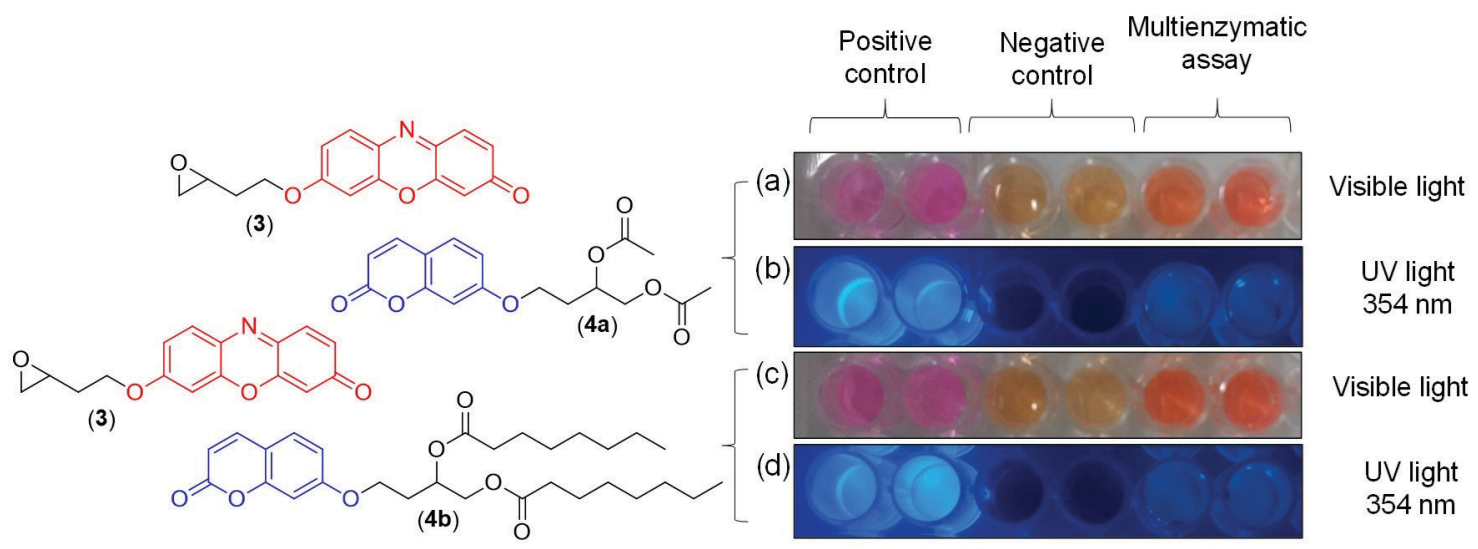

Figure 3. Multienzymatic monitoring for Bacillus cereus after 10 h. (a, b) Same assay with probes $\mathbf{3}$ and $\mathbf{4 a}$, observed with visible and $354 \mathrm{~nm}$ UV light, respectively; (c, d) same assay with probes $\mathbf{3}$ and $\mathbf{4 b}$ observed under visible and $354 \mathrm{~nm}$ UV light, respectively.

the same experiment. Although the enzymatic-enzymatic cascade model is already known in the literature, the simultaneous detection of this fluorogenic probe model has never been employed. The results were quantitative (Figure 2) and qualitative (Figure 3), with the aid of visible and UV light at $354 \mathrm{~nm}$. The methodology is a promising new tool in the screening of a large number of biological samples, such as collections of mutants and clones.

\section{Supplementary Information}

Supplementary information (NMR and EI-MS spectra) is available free of charge at http://jbcs.sbq.org.br as a PDF file.

\section{Acknowledgments}

The authors thank the CNPq (National Research Council, 140741/2013-5 and 307885/2013-5) and FAPESP-GSK (2014/50249-8) Brazil, for financial support.

\section{References}

1. Forchin, M. C.; Crotti, M.; Gatti, F. G.; Parmeggiani, F.; Brenna, E.; Monti, D.; ChemBioChem 2015, 16, 1571; Zhang, Y.; Shi, W.; Li, X.; Ma, H.; Sci. Rep. 2013, 3, ID 2830, doi 10.1038/ srep02830; Shen, W.; Zhang, J.; Mao, G.; Jiang, K.; Zhu, Q.; Biol. Pharm. Bull. 2009, 32, 1496.

2. Gonçalves, C. C. S.; Costa, B. Z.; Lima, M. L. S. O.; Fiorito, G. F.; Ruiz, A. L. T. G.; Oliveira, S. B. P.; Barbosa, G. O.; Carvalho, H. F.; Marsaioli, A. J.; Tetrahedron 2016, 72, 7235.

3. Lima, M. L. S. O.; Gonçalves, C. C. S.; Barreiro, J. C.; Cass, Q. B.; Marsaioli, A. J.; J. Braz. Chem. Soc. 2015, 26, 319.

4. Costa, B. Z.; Rodrigues, V. D.; Oliveira, V. M.; Ottoboni, L. M. M.; Marsaioli, A. J.; Braz. J. Microbiol. 2016, 47, 846.
5. Gonçalves, C. C. S.; Marsaioli, A. J.; Quim. Nova 2013, 36, 1587.

6. Sheng, Y.; Liu, K.; Wu, Q.; Oi, N.; Chen, H.; Reddy, K.; Jiang, Y.; Yao, K.; Li, H.; Li, W.; Zhang, Y.; Saleem, M.; Ma, W.-Y.; Bode, A. M.; Dong, Z.; Dong, Z.; Oncotarget 2014, 7, 30977.

7. Tallman, K. R.; Levine, S. R.; Beatty, K. E.; ACS Chem. Biol. 2016, 11, 1810.

8. Ladner, T.; Beckers, M.; Hitzmann, B.; Büchs, J.; Biotechnol. J. 2016, 11, 1605.

9. Janes, L. E.; Kazlauskas, R. J.; J. Org. Chem. 1997, 62, 4560 .

10. Elshal, M. F.; McCoy, J. P.; Methods 2006, 38, 317.

11. Hagan, S.; Tomlinson, A.; Ocul. Surf. 2013, 11, 219.

12. Beloglazova, N. V.; Speranskaya, E. S.; Wu, A.; Wang, Z.; Sanders, M.; Goftman, V. V.; Zhang, D.; Goryacheva, I. Y.; De Saeger, S.; Biosens. Bioelectron. 2014, 62, 59.

13. Purohit, S.; Sharma, A.; She, J.-X.; Biomed. Res. Int. 2015 , 2015, ID 326918.

14. Wahler, D.; Badalassi, F.; Crotti, P.; Reymond, J.-L.; Chem. Eur. J. 2002, 8, 3211.

15. Tufvesson, P.; Lima-Ramos, J.; Haque, N. A.; Gernaey, K. V.; Woodley, J. M.; Org. Process Res. Dev. 2013, 17, 1233.

16. Zadlo-Dobrowolska, A.; Szczygiel, M.; Koszelewski, D.; Paprocki, D.; Ostaszewski, R.; Org. Biomol. Chem. 2016, 14, 9146.

17. Wodtke, R.; Schramm, G.; Pietzsch, J.; Pietsch, M.; Löser, R.; ChemBioChem 2016, 17, 1263.

18. Gupta, R. D.; Sustainable Chem. Processes 2016, 4, 1.

19. Khersonsky, O.; Tawfik, D. S.; Annu. Rev. Biochem. 2010, 79, 471.

20. Reetz, M. T.; Bocola, M.; Wang, L. W.; Sanchis, J.; Cronin, A.; Arand, M.; Zou, J.; Archelas, A.; Bottalla, A.-L.; Naworyta, A.; Mowbray, S. L.; J. Am. Chem. Soc. 2009, 131, 7334.

21. Amrein, B. A.; Bauer, P.; Duarte, F.; Carlsson, A. J.; Naworyta, A.; Mowbray, S. L.; Widersten, M.; Kamerlin, S. C. L.; ACS Catal. 2015, 5, 5702. 
22. Renata, H.; Wang, Z. J.; Arnold, F. H.; Angew. Chem., Int. Ed. 2015, 54, 3351.

23. Turner, N. J.; Nat. Chem. Biol. 2009, 5, 567.

24. Bornscheuer, U. T.; Huisman, G. W.; Kazlauskas, R. J.; Lutz, S.; Moore, J. C.; Robins, K.; Nature 2012, 485, 185.

25. Zadlo, A.; Koszelewski, D.; Borys, F.; Ostaszewski, R.; ChemBioChem 2016, 17, 71.

26. Mantovani, S. M.; Oliveira, L. G.; Marsaioli, A. J.; J. Mol. Catal. B: Enzym. 2008, 52-53, 173.

27. Kračun, S. K.; Schückel, J.; Westereng, B.; Thygesen, L. G.; Monrad, R. N.; Eijsink, V. G. H.; Willats, W. G. T.; Biotechnol. Biofuels 2015, 8, 70.

28. Priestman, M. A.; Wang, Q.; Jernigan, F. E.; Chowdhury, R.; Schmidt, M.; Lawrence, D. S.; ACS Chem. Biol. 2015, 10, 433.

29. Wakata, A.; Lee, H. M.; Rommel, P.; Toutchkine, A.; Schmidt, M.; Lawrence, D. S.; J. Am. Chem. Soc. 2010, 132, 1578.

30. Johansson, M.; Tomankova, J.; Li, S.; Zamaratskaia, G.; Interdiscip. Toxicol. 2012, 5, 150.

31. Fu, Q.; Zhu, J.; van Eyk, J. E.; Clin. Chem. 2010, 56, 314.
32. Valentin, M. A.; Ma, S.; Zhao, A.; Legay, F.; Avrameas, A.; J. Pharm. Biomed. Anal. 2011, 55, 869.

33. Fu, Q.; Schoenhoff, F. S.; Savage, W. J.; Zhang, P.; van Eyk, J. E.; Proteomics: Clin. Appl. 2010, 4, 271.

34. Ho, S.-L.; Xu, D.; Wong, M. S.; Li, H.-W.; Chem. Sci. 2016, 7, 2695.

35. Jones, V. S.; Wu, J.; Zhu, S.-W.; Huang, R.-P.; Expert Rev. Mol. Med. 2016, 18, e15.

36. Logan, C.; Todorof, K.; Fiorillo, S. P.; Campbell, T. B.; Elder, J. H.; Borok, M.; Gudza, I.; Gwanzura, L.; Ndemera, B.; Lochhead, M. J.; Benson, C. A.; Schooley, R. T.; PLoS One 2016, 11, e0163616.

37. Shen, W.; Zhang, J.; Mao, G.; Jiang, K.; Zhu, Q.; Biol. Pharm. Bull. 2009, 32, 1496.

38. Bicalho, B.; Chen, L. S.; Grognux, J.; Reymond, J.-L.; Marsaioli, A. J.; J. Braz. Chem. Soc. 2004, 15, 911.

Submitted: July 17, 2017

Published online: October 17, 2017 